\title{
VZŤAH PREDROMÁNSKEHO KOSTOLA NA DEVÍNE K DALMÁTSKEJ ARCHITEKTÚRE
}

\author{
Relation of the pre-Romanesque Church at Devín \\ to Dalmatian Architecture
}

Martin Illáš

DOI: 10.17846/CL.2018.11.2.14-34

\begin{abstract}
ILLÁŠ, Martin. Relation of the pre-Romanesque Church at Devín to Dalmatian Architecture. The subject of the study is the structural and iconographic-iconological analysis of the ground-plan of the pre-Romanesque Great-Moravian church in Devín Castle from the 9 th century. The study also attempts to define the building stages that can be identified in the building development of the ground-plan. After a critical analysis, the building can be interpreted as an early-medieval adaptation of a defined model of the Dalmatian lateantique church through Dalmatian pre-Romanesque architecture. As the source, the three late-antique churches in Dalmatia used also in the early-middle ages may be identified (Bilice, Pridraga, Sutivan). The ground-plan of the Devín church may be analysed by several construction plans based on different planimetric methods of construction, from which one can be analogically applied in the plans of the three Dalmatian triconchs. The Devín church was probably constructed using a Carolingian foot. The ground-plan of the Devín church was a result of one building project, but two ground-plan elements are obviously the separate building interventions. One intervention is presented by a middle transverse foundation stripe serving as the base of the chancel screen which was a part of the original building plan. The second intervention is presented by the additional intervention in the masonry of the northern apse which can be interpreted as a rebuilding of the northern apse caused by the static disorder in the second building stage.
\end{abstract}

Keywords: church, triconch, Devin, Great Moravia, pre-Romanesque architecture, Dalmatian architecture

Abstrakt: ILLÁŠ, Martin. Vztah predrománskeho kostola na Devíne k dalmátskej architektú$r e$. Predmetom tejto štúdie je štrukturalistická a ikonograficko-ikonologická analýza pôdorysu predrománskeho velkomoravského kostola na Devínskom hrade z 9. storočia. Štúdia sa taktiež pokúša definovat stavebné etapy, ktoré možno identifikovat'v stavebnom vývoji pôdorysu. Po kritickej analýze možno stavbu interpretovat ako včasnostredovekú recepciu definovaného modelu dalmátskeho neskoroantického kostola sprostredkovanú dalmátskou predrománskou architektúrou. Ako vzor možno identifikovat tri neskoroantické kostoly v Dalmácii, ktoré boli využívané i vo včasnom stredoveku (Bilice, Pridraga, Sutivan). Pôdorys devínskeho kostola možno analyzovat pomocou niekolkých konštrukčných plánov založených na rôznych planimetrických konštrukčných metódach, z ktorých jednu možno aplikovat aj na pôdorysy troch dalmátskych trikonch. Devínsky kostol bol pravdepodobne konštruovaný s dížkovou mierou karolínskej stopy. Pôdorys devínskeho kostola bol výsledkom jedného stavebného projektu, avšak dva prvky pôdorysu sú zjavne samostatnými stavebnými zásahmi. Prvý zásah predstavuje stredný priečny základový pás, ktorý slúžil ako základ predoltárnej priečky, ktorá bola súčastou pôvodného projektu. Druhý stavebný zásah 
predstavuje dodatočný zásah do muriva severnej apsidy, ktorý možno interpretovat ako prestavbu severnej apsidy vyvolanú statickou poruchou a ako druhú stavebnú etapu.

Klúčové slová: kostol, trikoncha, Devín, Velká Morava, predrománska architektúra, dalmátska architektúra

Predmetom tejto štúdie je štrukturalistická a ikonograficko-ikonologická analýza ${ }^{1}$ pôdorysu včasnostredovekého kostola na Devínskom hrade. Štúdia sa zároveň pokúša definovat a interpretovat' stavebné fázy, resp. stavebné etapy, ktoré možno v stavebnom vývine pôdorysu identifikovat'. Štúdia nadväzuje na skoršiu autorovu prácu, ktorej obsahom je interpretácia funkcie, proveniencie a priestorového usporiadania tejto včasnostredovekej stavby na základe jej formálnej a dispozičnej analýzy a komparácie (Illáš 2011b).

Základy stavby boli archeologicky skúmané v rokoch 1921 - 22, 1935 a 1980, ked' bol odkrytý jej kompletný pôdorys (Plachá - Hlavicová 1981, 435-436; stručný prehlad výskumov v Štefanovičová 1993, 308-309 alebo Plachá - Hlavicová 2011, 73). Na základe výsledkov posledného výskumu z 80. rokov bola stavba interpretovaná ako kostol a prostredníctvom hrobov na okolitom pohrebisku bola datovaná do 2. polovice 9. storočia (Štefanovičová 1993, 309-311; Plachá - Hlavicová 2011, 89-101). ${ }^{2}$

Malý počet hrobov z 9. storočia a ich relatívne velká vzdialenost' od stavby, ako aj značné množstvo rímskeho stavebného materiálu sekundárne použitého v murive stavby sú príčinou pochybností o včasnostredovekom datovaní stavby a úvah o jeho neskoroantickom datovaní (Měřínský 2006, 608; Poláček 2008, 13). Také datovanie je však vylúčené superpozíciou stavby k objektu z 5. storočia a absenciou akéhokolvek relevantného nálezového kontextu zo 6. až 8. storočia, ktorý by svedčil o vzniku tejto murovanej stavby v tomto období, t. j. pred 9. storočím (Plachá - Hlavicová 2011, 75-77). ${ }^{3}$

Včasnostredoveký kostol na Devínskom hrade je svojím pôdorysom výnimočný v sakrálnej architektúre na území Vel'kej Moravy i v strednej Európe 9. storočia. ${ }^{4}$ Ide o trikonchu s trojicou identických apsíd na pôdoryse písmena $U$ umiestnených tesne pri sebe a s priemerom menším než je priemer lode. Pozdĺžna lod’ stavby je členená tromi priečnymi základovými pásmi deliacimi pôdorys na štyri nerovnako velké plochy. Stredný priečny základový pás nie je previazaný so základmi obvodových múrov. Základy severnej apsidy boli neskôr doplnené v interiéri aj exteriéri obmurovkou (obr. 1).

Výnimočná pôdorysná dispozícia stavby, ktorá vo väčšine odbornej literatúry venovanej tomuto kostolu stále ostáva nevyriešenou otázkou, je príčinou diametrálne odlišných interpretácií jej priestorového a funkčného usporiadania, ktoré sú založené na predpoklade členenia stavby na viac miestnostís rozličnými funkciami (napríklad Štefanovičová 1989, 118; Rodzińska-Chorąży 2000, 45-52; Vančo 2002, 38-39). Viaceré z týchto teoretických variantov možno z viacerých dôvodov vylúčit ako nepravdepodobné alebo celkom nereálne. Ako príklad možno uviest’ interpretáciu stavby ako paláca s palácovou kaplnkou, ktorá má byt najstarším príkladom spojenia profánnej

1 Tieto metodické východiská na účely výskumu predrománskej sakrálnej architektúry v Čechách, na Morave a na západnom Slovensku odporúča M. Vančo (2011, 152-153).

2 M. Vančo stavbu datuje až na koniec 9 . storočia $(2002,46)$. Najnovšie sa objavila úvaha o datovaní kostola dokonca pred polovicu 9. storočia (Chorvátová 2017, 118-121).

3 K. Harmadyová $(2012,353)$ nedávno uvádza (bez odkazu na relevantný zdroj), že pod základmi kostola bol odkrytý kolový objekt $z \mathrm{8}$. storočia, čo však nemá oporu v inej literatúre.

4 V strednej a západnej Európe možno v 9. storočí nájst̉ len niekolko kostolov s trikonchálnym pôdorysom: Müstair, Werden, Halberstadt, Neuss, Ingelheim, Fécamp, Querqueville a Wandrille (Illáš 2014, 166, Tab. VII). 
a sakrálnej stavby v stredoeurópskom prostredí a ktorého mladšie príklady sú známe z viacerých pol’ských lokalít z 2. polovice 10. a z 11. storočia (Rodzińska-Chorąży 2000, 50-51). Porovnanie s ostatnými kostolmi a palácovými, resp. nadštandardnými obytnými stavbami v prostredí Velkej Moravy a s ňou súvisiacich oblastiach (Panónia, Čechy), kde rezidenčný objekt bol vždy striktne oddelený od sakrálnej stavby, však vylučuje, že by tu v 9. storočí vzniklo také kompaktné spojenie sakrálneho a profánneho objektu, aké poznáme z druhej polovice 10. storočia na území Pol’ska (Illáš 2011b, 21). ${ }^{5}$ rovnakého dôvodu, ktorý je príčinou rozličných interpretácií priestorového a funkčného usporiadania stavby, sa rôznia aj názory na identifikáciu proveniencie tejto stavby, a to od longobardskej či rímskej kuriálnej reprezentačnej architektúry cez dalmátsku či balkánsku architektúru až po byzantskú architektúru (Štefanovičová 1993, 311; Vančo 2002, 39; Plachá Hlavicová 2011, 84-88; Ruttkay 2012, 87).

Zo všetkých alternatív interpretácie funkcie a usporiadania stavby sa po kritickej analýze ako najpravdepodobnejšia zdá interpretácia stavby ako kostola s jednou nedelenou pozdĺžnou lod’ou (Illáš 2011b, 22-23). K tomuto záveru vedie na jednej strane analýza zachovaných murív a kontext ostatných sakrálnych stavieb na území Velkej Moravy a na druhej strane formálna analýza dispozície stavby a jej komparácia s analogicky usporiadanými kostolmi z 5. - 6. storočia na území Dalmácie a Norica - s kostolom sv. Jána Krstitela v Sutivane (Vežić 2011, 38, 43), kostolom sv. Martina v Pridrage (Vežić 2011, 34-37, 40-42), kostolom neznámeho zasvätenia v Biliciach (Vežić 2011, 37, 42) a kostolom sv. Petra v Lendorfe-Holzi, ktorý svoju konečnú podobu trikonchy nadobudol po prestavbe v 6 . storočí (Glaser 2003, 427, 436). Minimálne tri z uvedených stavieb (nachádzajúce sa v Dalmácii) plnili svoju funkciu aj vo včasnom stredoveku a ešte niekolko dalších storočí (kostol sv. Martina v Pridrage je živým kostolom dodnes). Devínsky kostol sa s týmito stavbami zhoduje analogickou pôdorysnou dispozíciou s typickými charakteristickými znakmi (trikoncha s výrazne pozdľžnou lod’ou a s trojicou identických alebo takmer identických apsíd umiestnených tesne pri sebe s menším priemerom než je priemer lode), ako aj rozmermi viacerých parametrov (Illáš 2011b, 29-31). Priečne základové pásy odkryté v devínskej stavbe len „V úrovni pod dlážkou“ (napríklad Plachá - Hlavicová 2011, 84), ktoré nikde nevystupujú do takej výšky ako zachované obvodové murivo, neboli so všetkou pravdepodobnostou základmi priečok, ale boli len základmi prístenných interiérových lizén. Práve taký základový pás nesúci len pár prístenných lizén, nie murovanú priečku, nachádzame v jednom prípade dalmátskych neskoroantických kostolov (kostol sv. Jána Krstitela v Sutivane; Illáš 2011b, 30-31). ${ }^{6}$ Priečne základové pásy s lizénami teda delili interiér kostola na niekolko nerovnakých travé.

Tieto formálne zhody devínskeho kostola s dalmátskymi neskoroantickými kostolmi dovolujú identifikovat aj najpravdepodobnejšiu provenienciu devínskeho kostola - ide zrejme o recepciu určitého vymedzeného modelu dalmátskeho neskoroantického kostola prostredníctvom dalmátskej predrománskej architektúry, ktorá vo včasnom stredoveku aktívne či pasívne recipovala a transformovala domáce dalmátske neskoroantické vzory a predlohy (Illáš 2011b, 31-32, 37-38). Hoci v samotnej dalmátskej predrománskej architektúre nepoznáme analogickú predrománsku stavbu, ktorá by bola výsledkom podobnej recepcie, nie je to prekážkou. Dalmátska predrománska

5 Jednou z príčin, pre ktoré v prípade devínskej stavby nemohlo íst’ o rezidenčný či iný profánny objekt je existencia hrobov, ktoré by sotva mohli byt' uložené k stavbe, ktorá nebola kostolom. Relatívne vel'ká vzdialenost' hrobov z 9. storočia od kostola na Devíne nemôže byt' indíciou pre interpretáciu tejto stavby ako spojenia objektu s profánnou (palác) a sakrálnou funkciou (kaplnka), pričom hroby by boli ukladané práve pri sakrálnej časti stavby, ako najnovšie uvažujú M. Samuel a B. Pomfyová $(2015,100)$, pretože skupina uvedených hrobov sa nachádza bližšie práve k domnelej profánnej časti stavby, nie však k domnelej kaplnke.

6 Túto interpretačnú možnost’ priečnych základových pásov devínskeho kostola uvádza, no zároveň odmieta T. Rodzińska-Chorąży $(2000,37,46)$. 
architektúra tu - podobne ako v mnohých iných prípadoch - zachovala neskoroantické kostoly v Sutivane, Biliciach i Pridrage v celej ich zachovanej hmote a s minimálnymi zásahmi ich adaptovala prostriedkami predrománskeho umenia najmä s ohladom na včasnostredoveké požiadavky na liturgické funkcie a členenie sakrálneho priestoru (išlo najmä o vybavenie kostolov vnútornou kamenárskou výzdobou, predovšetkým predoltárnou priečkou). ${ }^{7}$

Pre dôslednú komparáciu devínskeho kostola s jeho dalmátskymi neskoroantickými analógiami je potrebné pokúsit sa i o štrukturalistickú a ikonograficko-ikonologickú analýzu ich pôdorysov.

V súvislosti s viacerými rozmerovými zhodami pôdorysu devínskeho kostola s pôdorysmi troch dalmátskych kostolov je potrebné zistit’, aká dľžková miera bola použitá pri konštrukcii pôdorysu devínskeho kostola. To je možné na základe zistenia, či rozmery jednotlivých parametrov pôdorysu devínskeho kostola po vyjadrení v niektorej dobovej dľžkovej miere zodpovedajú celým číslam a či nesú v sebe určitú, najmä krestanskú numerologickú symboliku, alebo majú aspoň všeobecne okrúhle hodnoty, prípadne či ide o násobky takých hodnôt (Vančo 2011, 152). ${ }^{8}$ Do úvahy prichádzajú v podstate dve dľžkové miery, ktorých použitie možno v strednej Európe 9. storočia najpravdepodobnejšie predpokladat', a to rímska stopa s typickou dížkou 29,6 cm (ktorú však vo včasnom stredoveku spravidla možno zaokrúhlit na $30 \mathrm{~cm}$ ) a karolínska stopa s dížkou oscilujúcou okolo $33,3 \mathrm{~cm} .{ }^{9}$

Z 52 sledovaných parametrov pôdorysu devínskeho kostola (podla pôdorysu v Plachá Hlavicová - Keller 1990,90$)^{10}$ je možné 31 vyjadrit v rímskych stopách a 27 v karolínskych stopách tak, aby rozmer i po zohladnení maximálnej tolerovatel’nej odchýlky v rozsahu jednej stopy zodpovedal číslu s určitou krestanskou symbolikou alebo nejakej všeobecne okrúhlej hodnote. Napriek určitej štatistickej prevahe parametrov vyjadritelných v rímskych stopách však nejde o rozdiel tak významný, aby sa dalo jednoznačne konštatovat použite rímskej stopy ako stavebnej dĺžkovej jednotky.

V troch neskoroantických dalmátskych trikonchách bola nepochybne použitá dlǐ̌ková miera rímskej stopy, takže by bolo možné predpokladat jej použitie aj v devínskom kostole. V rozmeroch devínskeho kostola a troch dalmátskych kostolov možno dokonca identifikovat' 8 zhodných rozmerov niektorých parametrov. Napriek tomu však nie je nevyhnutné predpokladat aj použitie zhodnej dížkovej miery. Ak boli zhody niektorých rozmerov devínskeho kostola a troch dalmátskych kostolov výsledkom úmyselnej recepcie, museli by ich hodnoty zodpovedat symbolickým číslam či iným okrúhlym hodnotám aj vtedy, ak by v prípade devínskej stavby bola použitá iná dížková miera než v prípade troch uvedených dalmátskych kostolov, t. j. karolínska stopa. Túto podmienku spíňa 5 zhodných rozmerov. Je tu však aj možnost', že rozmerové zhody v pôdorysoch devínskeho kostola s podobnými dalmátskymi kostolmi neboli výsledkom priamej a úmyselnej

$7 \quad$ K otázke vplyvu a prispôsobovania neskoroantických kostolov v byzantskej a chorvátskej Dalmácii pozri Jurković 2000, 182 alebo Marasović 2008, 204-211. K problému predrománskej transformácie neskoroantických kostolov na východnom Jadrane všeobecne pozri: Jurković 1988-1989, 42.

8 Rozmery kostolov boli pri projektovaní kostolov a konštrukcii ich pôdorysov, priestorov a hmoty intencionálne vyberané ako určité ustálené hodnoty, resp. ich násobky či podiely, ktoré boli podriadené predovšetkým symbolike prameniacej zo Svätého písma, a to bud priamo, alebo nepriamo, prostredníctvom imitovania iných sakrálnych stavieb slúžiacich ako vzor.

9 Použitie tzv. langobardskej stopy s dížkou $43 \mathrm{~cm}$ alebo $36,5 \mathrm{~cm}$ v našom prostredí možno sotva predpokladat', kedže používanie stôp s touto dĺžkou nie je v 9. storočí v strednej Európe spolahlivo doložené (napríklad Vančo 2011, 135).

10 Autor sledoval všetky šírkové a dížkové parametre všetkých štrukturálnych prvkov pôdorysu. Na účely tejto štúdie sa metrické rozmery pôdorysu z dôvodu nepravidelného priebehu zachovaného muriva, resp. len maltového podzákladového lôžka spravidla zaokrúhlili na celých $5 \mathrm{~cm}$. 
recepcie jednotlivých parametrov, ale boli dôsledkom použitia jedného či viacerých zhodných alebo podobných modulov a konštrukčných plánov. Preto je potrebné pokúsit’ sa identifikovat východiskové moduly a použité konštrukčné plány aplikované na pôdorysy všetkých analyzovaných stavieb.

Na pôdorys devínskeho kostola možno aplikovat viac konštrukčných plánov založených na rôznych planimetrických metódach výstavby: dynamické štvoruholníky, ${ }^{11}$ kvadratúry, ${ }^{12}$ $\mathrm{X}$-figúry, ${ }^{13}$ kružnice. ${ }^{14}$ Kritériom ich použitelnosti je ich komplexný vztah k reálnemu pôdorysu, t. j. že každý z nich musí vymedzovat niekolko parametrov pôdorysu kostola s maximálnou tolerovatelnou odchýlkou v rozsahu jednej stopy (Vančo 2011, 138, 152). ${ }^{15}$ Základom každého z aplikovaných konštrukčných plánov je pritom jeden základný východiskový rozmer, t. j. modul ${ }^{16}$ obsahujúci číslo s určitou krestanskou symbolikou, resp. okrúhlou hodnotou.

Konštrukčné plány identifikované $\mathrm{v}$ pôdoryse devínskeho kostola spolu navzájom súvisia a navzájom sa podmieňujú, pričom až spoločne vymedzujú všetky podstatné parametre pôdorysu kostola. Je zaujímavé, že takmer všetky aplikované konštrukčné plány sa priamo alebo nepriamo (prostredníctvom iného z plánov) odvíjajú od stredného priečneho základového pásu (od jeho západného líca). Stredný priečny základový pás preto napriek tomu, že nebol previazaný s obvodovým murivom, musel byt' súčastou pôdorysu kostola už od počiatku, pričom musel mat zásadný

11 Ide o planimetrickú konštrukciu, kde sa štvoruholníky radia za sebou tak, že súčet spoločnej dlžky prvého štvoruholníka (štvorca) a najbližšieho susedného štvoruholníka sa rovná uhlopriečke prvého z nich (štvorca), súčet dížok prvých dvoch štvoruholníkov a nasledujúceho tretieho štvoruholníka sa rovná spoločnej uhlopriečke prvých dvoch štvoruholníkov atd’. Matematicky možno súčet dížok prvých dvoch štvoruholníkov vyjadrit ako súčin dížky prvého z nich (štvorca) a $\sqrt{2}$, súčet dížok prvých troch štvoruholníkov vyjadrit ako súčin diľ̌ky prvého $\mathrm{z}$ nich (štvorca) a $\sqrt{3}$, súčet dížok prvých štyroch štvoruholníkov vyjadrit ako súčin dížky prvého z nich (štvorca) a $\sqrt{ } 4$, t. j. dvojnásobku prvého štvorca atd'. (napríklad Vančo 2002, 37-38).

12 Ide o aplikáciu štvoruholníkov alebo identických štvorcov, prípadne ich polovíc alebo dảších podielov alebo aj určitého počtu identických tzv. aditívnych obdî̌nikov pridávaných $\mathrm{k}$ iným konštrukčným plánom. Za osobitný variant systému kvadratúr možno považovat' i tzv. modulový raster (Hecht 1978, 62, $78)$.

13 Metóda tzv. X-figúr je variantom triangulácie, ked’ sa na pôdorys aplikujú rovnostranné trojuholníky tak, že základňa trojuholníka je umiestnená priečne na pozdlǐnu os stavby. K použitiu tohto systému pozri napríklad: T. Küntzel (2015, 1-60).

14 Systém kružníc možno bez problémov aplikovat na polkruhovo uzavreté apsidy a na centrálne stavby, no len tažko možno túto metódu aplikovat na kvadratické pôdorysy, ako to navrhol J. Pošmourný $(1964,187-$ 202), resp. ako to v podstate bez výhrad prijali další bádatelia (napríklad Struhár 1977; Rodzińska-Chorąży 2000, 36-37; Botek 2014, 50-51) napriek tomu, že J. Pošmourný (ako aj A. Struhár a T. Rodzińska-Chorąży $\mathrm{v}$ prípade devínskeho kostola) pri formulácii svojej hypotézy rektifikoval modulové systémy z idealizovaných, a preto nesprávnych pôdorysov, takže jeho závery sa nezakladajú na reálnych východiskách a sú mylné. Kriticky k použitiu Pošmourného kružnicového modulu (napríklad Vančo 2011, 136-138).

15 Rozhodujúcimi kritériami pre identifikáciu najpravdepodobnejšie použitého konštrukčného plánu je najmä jeho jednoduchost', komplexné pokrytie hlavných štrukturálnych prvkov a podstatných parametrov pôdorysu, vzájomná súvislost jednotlivých súčastí konštrukčného plánu a rozmery zodpovedajúce krestanskej symbolickej numerológii. Rovnako je dôležité, ak sa viaceré použitelné konštrukčné plány navzájom doplňajú. Takto identifikované konštrukčné plány skúmanej stavby možno považovat za najreálnejšie, pričom možno zároveň predpokladat', že takýto postup konštrukcie pôdorysu stavby použil i stredoveký stavitel.'

16 Definíciu modulu formuluje už Vitruvius (Vitruvius 1979, 99) ako čast’ celku, ktorá je prijatá za východisko. Nezáleží na tom, či ide o číselný údaj transformovaný do rozmerov stavby alebo ide o planimetrický útvar, ktorého kombinovaním sa konštruuje pôdorys a hmota stavby. Táto transformácia a kombinácia spočíva v násobení a delení modulu ale aj v inom matematickom usporiadaní. 
význam pre priestorové i funkčné usporiadanie kostola. Zdá sa, že najskôr šlo o septum, resp. cancellum, t. j. predoltárnu priečku rozdelujúcu interiér kostola na dva základné priestory - priestor pre veriacich (quadratum populi) a priestor pre liturgiu a kňazov (presbyterium) (Marasović 2008, $187,192,196)$.

Konštrukčný plán devínskeho kostola založený na dynamických štvoruholníkoch ${ }^{17}$ sa priamo odvíja od západného líca stredného základového pásu, ktorý predstavuje jeho konštrukčný stred (obr. 2.1). Siet dynamických štvoruholníkov pozostáva zo západnej a východnej časti. Západná čast pozostáva $\mathrm{z}$ dvoch dynamických štvoruholníkov, východná čast' pozostáva zo štyroch dynamických štvoruholníkov. Siet’ dynamických štvoruholníkov vymedzuje exteriér stavby na západe (s odchýlkou $25 \mathrm{~cm}$ ), západný priečny základový pás (jeho východné líce; s odchýlkou $20 \mathrm{~cm}$ ), stredný priečny základový pás (jeho západné líce), napojenie severnej a južnej apsidy na lod' v exteriéri (s odchýlkou $25 \mathrm{~cm}$ ), záver východnej apsidy v interiéri, t. j. východný záver celého interiéru kostola (s odchýlkou $10 \mathrm{~cm}$ ), a exteriérovú šírku lode. Východiskovým rozmerom, t. j. modulom, je tu exteriérová šírka lode $(680 \mathrm{~cm})$, ktorá určuje rozmery prvého dynamického štvoruholníka (štvorca).

Na kvadratúrach sú založené tri konštrukčné plány, ktoré možno identifikovat’ v pôdoryse devínskeho kostola. Prvý z nich priamo vychádza z konštrukčného plánu založeného na dynamických štvoruholníkoch, je vlastne jeho iným vyjadrením (obr. 2.2, plná čiara). Tento konštrukčný plán pozostáva $\mathrm{z}$ radu troch identických štvorcov, z ktorých dva zodpovedajú obom štvorcom, ktoré sú častou siete dynamických štvoruholníkov, a tretí zodpovedá tretiemu, štvrtému a piatemu dynamickému štvoruholníku vo východnej časti siete dynamických štvoruholníkov. Týmto konštrukčným plánom založeným na kvadratúrach sú vymedzené totožné parametre pôdorysu ako v prípade konštrukčného plánu založeného na dynamických štvoruholníkoch (s výnimkou západného exteriéru stavby). Modulom je tu rovnako exteriérová šírka lode $(680 \mathrm{~cm})$, ktorá určuje rozmery identických štvorcov.

Druhý konštrukčný plán založený na kvadratúrach pozostáva len z jedného štvorca (obr. 2.2, prerušovaná čiara). Štvorec nadväzuje na konštrukčný plán založený na dynamických štvoruholníkoch, a to na jeho východné ukončenie (s odchýlkou $10 \mathrm{~cm}$ ). Štvorec má dížku strany $1145 \mathrm{~cm}$. Štvorec vymedzuje záver východnej apsidy v interiéri, t. j. východný záver celého interiéru kostola, d’alej východný priečny základový pás (jeho západné líce) a záver severnej i južnej apsidy v interiéri, t. j. celkovú interiérovú šírku presbytéria. Na tento konštrukčný plán bezprostredne nadväzuje konštrukčný plán založený na kružniciach (vid’ nižšie).

Tretí konštrukčný plán založený na kvadratúrach (obr. 3.1) nadväzuje na konštrukčný plán založený na dynamických štvoruholníkoch, resp. na prvý konštrukčný plán založený na kvadratúrach, a to na ich konštrukčný stred (západné líce stredného priečneho základového pásu). Tento konštrukčný plán pozostáva $\mathrm{z}$ dvoch identických štvorcov, ktoré vymedzujú stredný priečny základový pás (jeho západné líce), východné ukončenie pozdĺžneho priestoru kostola, t. j. vítazný oblúk východnej apsidy (s odchýlkou $10 \mathrm{~cm}$ ), a interiérovú šírku lode. Modulom je tu interiérová šírka lode $(540 \mathrm{~cm})$. Na tento konštrukčný plán nadväzuje konštrukčný plán založený na kružniciach (pozri nižšie), pretože je ním určený východný interiér severnej a južnej apsidy, a to na východnom ukončení pozdĺžneho priestoru kostola.

17 Na pôdorys devínskeho kostola aplikoval metódu dynamických štvoruholníkov M. Vančo (2000, 78, 107 108; 2002, 37-38), ktorý ju označuje ako „dynamické obdľžniky“, hoci jej súčastou okrem obdĺžnikov sú i štvorce. M. Vančo však vo svojej aplikácii dynamických štvoruholníkov na pôdorys devínskeho kostola vychádzal z čiastočne nesprávneho pôdorysu, pretože používa interiérovú dľžku druhého priestoru od východu kostola (t. j. medzi východným a stredným priečnym základovým pásom) $240 \mathrm{~cm}$, kým v skutočnosti tento priestor má interiérovú dížku $170 \mathrm{~cm}$. 
Konštrukčný plán založený na X-figúrach nenadväzuje na totožné východisko, ako každý z vyššie opísaných konštrukčných plánov. Tento konštrukčný plán pozostáva z jeden a pol $\mathrm{X}$-figúry (obr. 3.2). Jeho konštrukčným stredom je interkolumnium stredného priečneho základového pásu. Konštrukčný plán vymedzuje interiér stavby na západe, stredný priečny základový pás (jeho interkolumnium), záver východnej apsidy v exteriéri a interiérovú šírku lode. Modulom je tu interiérová šírka lode $(540 \mathrm{~cm})$. Hoci tento konštrukčný plán vymedzuje niekolko parametrov pôdorysu, nemá s ostatnými opísanými konštrukčnými plánmi súvislost', predovšetkým nemá totožné východisko (západné líce stredného priečneho základového pásu). Tento konštrukčný plán nie je pre výstavbu pôdorysu kostola dôležitý, kedže ním vymedzené parametre pôdorysu možno vymedzit i na základe ostatných opísaných konštrukčných plánov a manipuláciou s hrúbkou muriva $(65-70$, resp. až $75 \mathrm{~cm})$.

Konštrukčný plán založený na kružniciach pozostáva z troch identických kružníc (obr. 2.2). Kružnice nadväzujú na druhý konštrukčný plán založený na kvadratúre, t. j. na ním vymedzené interiérové závery apsíd, ako aj na tretí konštrukčný plán založený na kvadratúrach, t. j. na ním vymedzené interiérové východné ukončenie pozdľžneho priestoru kostola, ktoré zároveň určuje východný interiér severnej a južnej apsidy. Kružnice vymedzujú interiér všetkých troch apsíd. Majú priemer $340 \mathrm{~cm} .^{18}$

Z uvedených analýz vyplýva, že primárnu dôležitost’ mal konštrukčný plán založený na dynamických štvoruholníkoch a zároveň jeho variant $\mathrm{v}$ podobe prvého konštrukčného plánu založeného na kvadratúrach. Na tieto dva konštrukčné plány nadväzuje druhý a tretí konštrukčný plán kvadratúr. Konštrukčný plán kružníc nadväzuje až na druhý a tretí konštrukčný plán kvadratúr. Tieto súvislosti zároveň dovolujú rekonštruovat i postup projektanta pri plánovaní pôdorysu. ${ }^{19}$

Konštrukčný plán dynamických štvoruholníkov a prvý konštrukčný plán založený na kvadratúrach vymedzujú na ploche pôdorysu devínskeho kostola niekol'ko plôch, ktorým možno pripísat špecifické funkcie priestorového usporiadania kostola. Najzápadnejší z dynamických štvoruholníkov a tri identické štvorce vymedzujú štyri plochy: plochu od západného exteriéru stavby po západný priečny základový pás, plochu od západného priečneho základového pásu po stredný priečny základový pás, plochu od stredného priečneho základového pásu po exteriérové napojenie apsíd na obvodové múry kostola (na tejto ploche sa nachádza východný priečny základový pás) a plochu od exteriérového napojenia apsíd na obvodové múry kostola po interiérový záver východnej apsidy. Takto vymedzené plochy možno vzhladom na obvyklé interiérové usporiadanie kostolov interpretovat' najskôr ako vstupné travé, ${ }^{20}$ d’alej vlastnú lod' ako priestor pre veriacich (quadratum populi) a presbyterium pozostávajúce z oltárneho priestoru a sanktuária. Zároveň je oboma uvedenými konštrukčnými plánmi určená pravdepodobná poloha predoltárnej priečky na strednom priečnom základovom páse. Umiestnenie oltára možno predpokladat na východnom

18 Priemer apsíd je vo vítaznom oblúku $330 \mathrm{~cm}$, no v najširšom mieste interiéru apsíd dosahuje až $340 \mathrm{~cm}$ (v najzachovalejších miestach pôdorysu, t. j. v severnej a východnej apside), preto sa v tejto štúdii berie za základ konštrukčného plánu kružníc väčší z oboch rozmerov. Apsidy majú v dôsledku toho mierne podkovovitý pôdorys.

19 Je pravdepodobné, že stavební remeselníci aj v teréne zopakovali všetky konštrukčné planimetrické postupy, ktoré použil projektant „za stolom“ v malej mierke (Čiháková - Müller 2015, 13, 19). Plánovanie pôdorysu v teréne prebiehalo nepochybne tou najjednoduchšou metódou - použitím kolov a povrazov (Hecht 1978, 79-81). Pri vytyčovaní pôdorysu stavby v teréne vo vel'kej mierke tak nevyhnutne vznikali rôzne chyby a nepresnosti, no tie mohli byt aj dôsledkom modifikácie a improvizácie pri realizácii stavby (Čiháková - Müller 2015, 9).

20 Toto vstupné travé je svojím umiestnením a virtuálnym priestorovým vymedzením snád’ pozostatkom narthexu či predlodia (pronaos) v úplne redukovanej forme. Narthex ani pronaos už vo včasnostredovekom kontexte neplnili svoju obsahovú ani formálnu funkciu. 
priečnom základovom páse (Illáš 2011b, 31), ${ }^{21}$ ktorý bol vymedzený druhým konštrukčným plánom založeným na kvadratúrach; tento druhý konštrukčný plán kvadratúr by teda vymedzoval celý posvätný priestor kostola od oltára po závery všetkých troch apsíd. Uvedenými postupmi teda možno identifikovat všetky podstatné prvky interiéru kostola.

Na rozdiel od vyššie uvedených neskoroantických dalmátskych trikonch, ktoré predstavujú najbližšie analógie $\mathrm{k}$ devínskemu kostolu, presbytérium devínskeho kostola zahŕňa všetky tri apsidy, pričom oltár s predoltárnou priečkou je vysunutý pred trojapsidový záver presbytéria. V uvedených neskoroantických trikonchách bol oltár umiestnený vo východnej apside a tá bola od ostatného priestoru kostola oddelená predoltárnou priečkou, resp. ohradou. Uvedený rozdiel súvisí so zmenou liturgickej organizácie a funkcie bočných priestorov presbytéria, ktoré sa v neskorej antike spravidla využívali ako prothesis a diakonikon. Vo včasnom stredoveku táto obsahová stránka bočných priestorov presbytéria zanikla, resp. bola nahradená inou funkciou (najmä bočné oltáre), hoci formálne usporiadanie ostalo zachované (Jurković 1988-1989, 43-44; Marasović 2008, 192). Včasnostredoveké priestorové vymedzenie trikonchálneho záveru podobné devínskemu kostolu môžeme nájst’ napríklad v kostole Najsvätejšieho Spasitela pri prameni Cetiny (4. štvrtina 9. storočia, Chorvátsko), kde oltár nebol umiestnený vo východnej apside ale v krížení osí troch apsíd a predoltárna priečka oddelovala od lode celé trojapsidové presbytérium (Marasović 2011, 53).

Otázku môže vzbudzovat nápadné vysunutie predoltárnej priečky hlboko do priestoru lode, čím je priestor pre veriacich značne skrátený. Táto situácia nie je až tak výnimočná či neobvyklá, ako by sa mohlo zdat. V neskorej antike bola poloha oltára krestanského chrámu značne flexibilná, oltár mohol byt’ umiestnený až uprostred lode kostola. Vo včasnostredovekých kostoloch, ktoré tým či oným spôsobom recipovali či nadväzovali na neskoroantické vzory a medzi ktoré možno zaradit i kostol na Devíne, mnohokrát preberali aj výrazné vysunutie oltára spolu s predoltárnou priečkou do priestoru lode (napríklad kostol sv. Petra v Drage, ostrov Rab, Chorvátsko, 1. polovica 11. storočia; Marasović 2009, 121). Devínsky kostol síce neprevzal túto situáciu zo svojich vzorov, ale poloha oltára tu vyplynula $\mathrm{z}$ aplikácie sústavy konštrukčných plánov, z ktorých ten základný bol prevzatý z neskoroantických vzorov (vid’ nižšie). Výrazné vysunutie preoltárnej priečky do priestoru lode však nie je neznáme ani v iných včasnostredovekých kostoloch strednej a západnej Európy (napríklad kostol sv. Lucia, Walenstadt, 8. storočie, Švajčiarsko, Sennhauser 2003, 201; kostol sv. Ruperta, tzv. Virgilova bazilika, Salzburg, 774, Rakúsko, Jacobsen 1989, 181; kostol sv. Štefana, Böckweiler, 11. storočie, Nemecko, Dehio 1984, 133). Napokon, priestor pre veriacich $\mathrm{v}$ devínskom kostole mal v porovnaní s ostatnými vel'komoravskými kostolmi štandardnú a obvyklú rozlohu: V devínskom kostole možno plochu priestoru pre veriacich podla vyššie uvedených záverov rekonštruovat's vel'kostou asi $48,6 \mathrm{~m}^{2}$. Pre porovnanie možno uviest' plochu lode 1. kostola v Starom Měste „Na Valách“ (asi $39 \mathrm{~m}^{2}$ ), 4. kostola v Mikulčiciach - Valoch (asi $34 \mathrm{~m}^{2}$ ) alebo kostola sv. Jána v Modré (asi $42 \mathrm{~m}^{2}$ ).

Identifikácia konštrukčných plánov ako aj modulov, ktoré boli základom ich výstavby, umožňuje zo všetkých parametrov pôdorysu devínskeho kostola vyčlenit štyri hodnoty, ktoré predstavujú moduly. Ide o exteriérovú šírku lode $(680 \mathrm{~cm})$, celkovú interiérovú šírku presbytéria $(1145 \mathrm{~cm})$, interiérovú šírku lode $(540 \mathrm{~cm})$ a interiérový priemer apsíd $(340 \mathrm{~cm})$. Prirátat $\mathrm{k}$ nim možno i hrúbku muriva (na úrovni zachovaného základového muriva alebo podzákladového maltového lôžka 65-70 cm, v zachovanom nadzákladovom murive miestami až $75 \mathrm{~cm}$ ), ktorá v spojení s každým konštrukčným plánom dotvorila finálny pôdorys, no tu nejde o modul. Štyri

21 Nie je vylúčené, že východný priečny základový pás v devínskom kostole, na ktorom bol pravdepodobne umiestnený oltár, mal zároveň i funkciu stupňa zvýšenej podlahy presbytéria - to však nemožno zo zachovanej situácie odkrytých základov vôbec preukázat. 
modulové rozmery predstavujú základné hodnoty podstatné pre konštrukciu pôdorysu. Práve na základe tohto súboru podstatných parametrov možno zodpovedat' otázku, ktorá dližková miera bola použitá pri výstavbe devínskeho kostola.

Len dva z modulov možno v súlade s vyššie uvedenými kritériami hladania použitej dĺžkovej miery uspokojivo vyjadrit v rímskych stopách, avšak v karolínskych stopách možno vyjadrit všetky štyri moduly. Hodnota hrúbky muriva je vyjadritelná tak v rímskych ako aj karolínskych stopách, ale karolínske stopy poskytujú menšie odchýlky a jednoznačnejšiu hodnotu. Týmto spôsobom možno uvedených pät rozmerov vyjadrit v karolínskych stopách (k. s.) takto: $680 \mathrm{~cm}=$ 20,4 k. s. (ideálne 20), $1145 \mathrm{~cm}=34,4 \mathrm{k}$. s. (ideálne 35), $540 \mathrm{~cm}=16,2 \mathrm{k}$. s. (ideálne 16), $340 \mathrm{~cm}=$ 10,2 k. s. (ideálne 10) a 65-70 až $75 \mathrm{~cm}=1,9-2,1$ k. s. až 2,3 k. s. (ideálne 2).

Uvedené hodnoty obsahujú jednak čísla s krestanskou symbolikou (číslo 10 a číslo 16 ako dvojnásobok čísla 8$)^{22}$ a jednak čísla s okrúhlou hodnotu (číslo 20 a číslo 35). Hodnote hrúbky muriva (číslo 2) nemožno pripisovat osobitný význam, kedže hrúbka muriva je spravidla len technickým parametrom. ${ }^{23}$ Pritom v zachovanej hmote devínskeho kostola ide zväčša len o základové murivo, ktoré je užšie, a iba v dvoch častiach je vo väčšom rozsahu zachované nadzákladové murivo širšie než základy, ${ }^{24}$ takže zistená hrúbka muriva kolíše.

Zdá sa teda pravdepodobné, že pôdorys devínskeho kostola bol konštruovaný s použitím dližkovej miery karolínskej stopy.

Takto vykonaná štrukturalistická a ikonograficko-ikonologická analýza pôdorysu devínskeho kostola dovoluje jednak vysvetlit funkčné usporiadanie jednotlivých priestorov kostola a ich vzájomné vztahy a jednak pochopit’ aj zdanlivo problematické umiestnenie priečnych základových pásov a ich nepravidelný rytmus ako aj ich funkciu.

Po štrukturalistickej a ikonograficko-ikonologickej analýze pôdorysu devínskeho kostola je potrebné vrátit sa ku komparácii s vyššie uvedenými dalmátskymi trikonchami a zistit, či je možné $\mathrm{v}$ ich pôdorysoch nájst' konštrukčné plány analogické niektorému z vyššie identifikovaných (ako to odporúča M. Vančo, 2011, 152).

Je pozoruhodné, že v pôdorysoch všetkých troch dalmátskych trikonch, ktoré predstavujú $\mathrm{z}$ dispozičného hladiska najbližšie analógie $\mathrm{k}$ devínskemu kostolu, možno identifikovat konštrukčné plány analogické svojou výstavbou prvému konštrukčnému plánu kvadratúr, ktorý možno identifikovat v pôdoryse devínskeho kostola. Nie je pritom samozrejme vylúčené, že pri konštrukcii týchto kostolov mohli byt použité aj iné konštrukčné plány, napríklad založené na tzv. zlatom reze (Pejaković 2000, 118-119).

V pôdoryse kostola v Biliciach (obr. 4) ide o rad troch identických štvorcov, ktoré vymedzujú interiérovú šírku lode, exteriér stavby na západe, interkolumniá stredného páru interiérových lizén, východné líce východného páru interiérových lizén a interkolumniá vítazného oblúka východnej apsidy. Na východnom ukončení konštrukčného plánu leží zároveň stred východnej apsidy. Modulom je interiérová šírka lode $(550 \mathrm{~cm}$; ideálne 18 rímskych stôp).

22 Číslo osem symbolizuje ôsmy deň stvorenia sveta, ktorým bola v plnosti časov smrt' Krista na kríži za odpustenie hriechov, symbolizuje teda zmŕtvychvstanie Pána (Lurker 2005, 356). Č́́slo desat’ symbolizuje najmä počet Božích prikázaní (Lurker 2005, 89).

23 Hrúbku muriva samotnú nemožno považovat’ za prameň exaktného určenia velkosti základnej dĺžkovej miery a odvodzovat' z nej modul a ostatné rozmery pôdorysu. Hrúbka múru (ktorú napokon vo väčšine prípadov vel'komoravskej architektúry poznáme len v úrovni základového muriva) bola podmienená primárne požiadavkami statiky stavby, sekundárne aj aplikáciou konštrukčného plánu (Čiháková - Müller 2015, 16).

$24 \mathrm{~V}$ severnej apside do výšky $90 \mathrm{~cm}$ a v strednej časti severného múru lode v mieste napojenia stredného priečneho základového pásu do výšky 120 cm (Plachá - Hlavicová 2011, 73, tiež obr. 38 na s. 74; Samuel Pomfyová 2015, 98). 
V pôdoryse kostola sv. Martina v Pridrage (obr. 5) ide o rad troch identických štvorcov, ktoré vymedzujú interiérovú šírku lode, interkolumnium západnej steny lode, interkolumniá stredného páru interiérových lizén, interkolumniá východného páru interiérových lizén a interkolumniá vítazného oblúka východnej apsidy. Modulom je interiérová šírka lode $(580 \mathrm{~cm}$; ideálne 20 rímskych stôp).

V pôdoryse kostola sv. Jána Krstitela v Sutivane (obr. 6) ide o rad dvoch identických štvorcov a jedného obdĺžnika s dĺžkou zodpovedajúcou $2 / 3$ dľžky štvorca; vymedzujú interiérovú šírku lode, exteriér stavby na západe (obdľžnik), západné líce západného páru interiérových lizén, východné líce východného páru interiérových lizén a exteriérové napojenie východnej apsidy na bočné apsidy. Na východnom ukončení konštrukčného plánu leží zároveň stred východnej apsidy. Modulom je interiérová šírka lode ( $445 \mathrm{~cm}$; ideálne 14 alebo 15 rímskych stôp).

Vo všetkých troch uvedených dalmátskych kostoloch sú štvorcami, resp. obdľžnikom, ktoré vytvárajú konštrukčný plán, zjavne vymedzené funkčne determinované plochy, resp. priestory definované ako samostatné travé. Na západe ide o vstupné travé, ${ }^{25} \mathrm{v}$ strede je vymedzená vlastná lod' (quadratum populi, priestor pre zhromaždenie laických účastníkov liturgie) a na východe presbytérium s apsidami (kde sa nachádza oltár a pre neskorú antiku typické diakonikon, prothesis ale aj subsellia). Tento vztah konštrukčného plánu k funkčnému usporiadaniu sakrálneho priestoru v dalmátskych trikonchách oprávňuje vyššie uvedený predpoklad, že podobný význam konštrukčného plánu pre funkčné usporiadanie stavby možno očakávat i v devínskom kostole.

Devínsky kostol sa teda zhoduje s tromi dalmátskymi trikonchami nielen formálnymi znakmi pôdorysnej dispozície a niektorými rozmermi, ale aj konštrukčným plánom založeným na kvadratúrach. Otázku môže vzbudzovat' skutočnost', že medzi vznikom troch uvedených neskoroantických dalmátskych kostolov, v ktorých sa aplikoval uvedený konštrukčný plán, a vznikom predrománskeho devínskeho kostola, ked’ sa aplikoval znovu, uplynulo približne tri a pol storočia. Je to však len zdanlivý problém. Včasnostredoveký stavitel' zvolil aplikáciu dispozície, ako aj konštrukčného plánu stále zachovaného a funkčného kostola (kostolov). Tento kostol, resp. kostoly, ktoré si stavitel' zvolil za inšpiračný zdroj, tak plnili úlohu prostredníka medzi neskoroantickou a včasnostredovekou stavitel'skou praxou. Navyše, v predrománskej dalmátskej architektúre, ktorá recipovala a transformovala niektoré neskoroantické typy a modely sakrálnych stavieb, sa prostredníctvom stavitel’skej tradície mohli zachovat i metódy konštrukcie pôdorysu alebo minimálne vedomie o určitom planimetrickom usporiadaní pôdorysov kostolov. Včasnostredoveký stavitel' ich len rozvinul a komplexne skombinoval s inými planimetrickými aplikáciami. K aplikácii neskoroantických konštrukčných metód vo včasnostredovekej stavbe by sotva mohlo dôjst', ak by sa neskoroantické kostoly, v ktorých sa tieto metódy aplikovali, vôbec nedochovali - nebol by k dispozícii žiadny prostredník, ktorý by bol nositelom stavitel'ských zvyklostí a postupov. Tradícia stavitel'ských zvyklostí počas dlhých období si vyžaduje bud' zachovanie stavebného diela a ideálne aj jeho funkcie, alebo ich opakované aplikovanie v priebežne budovaných stavebných dielach. ${ }^{26} \mathrm{~V}$ prípade troch uvedených dalmátskych kostolov je naplnená podmienka zachovania

25 Ako sme už uviedli, môže íst’ o redukované predlodie (pronaos) či redukovaný narthex, ktorých funkcia sa napriek redukovanej forme mohla v týchto neskoroantických stavbách ešte zachovat' (išlo by teda zrejme o priestor pre katechumenov alebo dočasne vylúčených členov obce konajúcich pokánie alebo vykonávajúcich cirkevný trest). V kostole v Pridrage je západné vstupné travé akcentované tromi interiérovými slepými arkádami spočívajúcimi na západnom a strednom páre lizén.

26 Vzory a inšpiračné zdroje je vždy potrebné hladat primárne v tých stavbách, ktoré existovali a plnili svoju funkciu v dobe vzniku skúmanej stavby, prípadne ktoré síce vznikli aj omnoho skôr, ale v dobe vzniku analyzovaného kostola stále plnili svoju funkciu. Inak by bolo sotva možné zdôvodnit', že by sa pri vzniku skúmanej stavby architektonická idea uplatnila bez toho, že by bola v danej dobe obsahom nejakej existujúcej, ideálne ešte funkčnej stavby (Illáš 2014, 163). 
neskoroantických stavebných diel, ktoré tak mohli sprostredkovat stavitelskú prax medzi neskorou antikou a včasným stredovekom.

Na základe uvedených zistení možno vyslovit záver, že tak formálna ako aj štrukturalistická a ikonograficko-ikonologická analýza potvrdzuje názor, že devínsky kostol je importom dalmátskej predrománskej architektúry, ktorá v tomto prípade prevzala osobitný model neskoroantického trikonchálneho kostola.

Je navyše vel'mi pravdepodobné, že devínsky kostol vznikol priamo ako dielo stavitela, ktorý velmi intímne poznal dalmátsku architektúru a ktorý z Dalmácie priamo pochádzal. Svedčí pre to jednak volba pôdorysného modelu kostola vyskytujúceho sa v Dalmácii a jednak znaloste neskoroantických stavieb, ich parametrov a planimetrickej štruktúry.

Velmi pravdepodobné je i to, že z Dalmácie pochádzali dokonca aj stavební remeselníci, ktorí devínsky kostol vybudovali. Stavební remeselníci ovplyvňujú primárne technickú a technologickú stránku stavby, predovšetkým technológiu murovania (Illáš 2014, 171). Murivo devínskeho kostola je vybudované technikou opus incertum - z len hrubo upravených nepravidelne kladených kusov lomového kameňa - nie je vybudované z tenkých kamenných platní ako väčšina kostolov na území Vel'kej Moravy i strednej Európy, čo bola technika typická pre tradíciu merovejsko-karolínskeho stavitel'stva (Vančo 1998, 125). Opus incertum je typicky antická stavebná technika, ktorá však najmä v Dalmácii ostala takmer výlučne používaným spôsobom murovania i vo včasnom stredoveku (Marasović 2008, 291). Jej použitie na Devíne možno vysvetlit priamou účastou dalmátskych stavebných remeselníkov pri budovaní kostola. Použitie tejto stavebnej techniky spolu s ostatnými väzbami na Dalmáciu podporuje správnost tézy o dalmátskom pôvode devínskeho kostola. ${ }^{27}$

Inou súčastou technickej a technologickej stránky stavby je použitá dížková miera. Výber dížkovej miery bol zrejme rovnako závislý od volby stavebných remeselníkov. Podla vyššie uvedených zistení bola $\mathrm{v}$ devínskom kostole použitá karolínska stopa. Ak sa výstavby devínskeho kostola zúčastňovali stavební remeselníci pochádzajúci z Dalmácie, môže sa zdał̉ nepravdepodobné, že by použili ako stavebnú dľžkovú mieru karolínsku stopu a nie rímsku stopu, ktorá bola v Dalmácii tradične používaná i vo včasnom stredoveku. Architektúra v chorvátskej Dalmácii však aktívne preberala podnety $\mathrm{z}$ karolínskej architektúry a organizátormi viacerých stavebných projektov boli priamo duchovní pochádzajúci z karolovskej ríše; to rovnako platí pre stavitelov či majstrov, ktorí v Dalmácii realizovali stavebné projekty. ${ }^{28}$ Je teda pravdepodobné, že v chorvátskej Dalmácii pôsobili i stavební remeselníci pochádzajúci z ríše a aplikujúci karolínsku stopu, ktorej použitie v Dalmácii zdomácnelo.

V literatúre venovanej devínskemu kostolu sa vo všeobecnosti zhodne konštatuje jeho jednofázový stavebný vývoj (napríklad Štefanovičová 1993, 309; Vančo 2002, 36; Plachá - Hlavicová 2011, 75). Pôdorys devínskeho kostola vznikol v zásade ako jeden stavebný projekt, nevznikol vo viacerých stavebných fázach. Napriek tomu dva prvky pôdorysu sú zjavne samostatnými stavebnými zásahmi. Jedným je stredný priečny základový pás, ktorý nebol previazaný s obvodovým murivom, druhým je dodatočné zosilnenie múru severnej apsidy.

Pokial ide o stredný priečny základový pás, jednoznačne možno odmietnut interpretáciu, že išlo o vyrovnanie poklesu terénu pod dlážkou kostola. ${ }^{29}$ Ak by malo íst’ o podmurovanie dláž-

27 To zároveň svedčí proti téze o byzantskom pôvode devínskeho kostola (Ruttkay 2012, 87). Indíciou, ktorá rovnako vylučuje súvislost' kostola na Devíne s byzantskou architektúrou, je aj charakter jeho mált a omietok, ktoré nemajú žiadny znak charakteristický pre byzantské stavebníctvo - chýba v nich technologická prímes živočíšnych chlpov či rastlinných vláken, napríklad slamy či kúdela, typická pre byzantské omietky (Hammer 2008, 126).

28 Napríklad Teodobert, Gumpertus, Mengausus či Tehoderus (Marasović 2008, 162-163).

29 Ako sa domnievajú najmä autorky výskumu kostola (napríklad Plachá - Hlavicová 2011, 75). 
ky kostola z dôvodu poklesu podložia, zrejme by toto vyrovnanie bolo vykonané v rozsahu a spôsobom zodpovedajúcim poruche podložia, nie však v architektonickej forme presne vymeraného múru (Illáš 2011, 22). Z vyššie uvedenej štrukturalistickej a konštrukčnej analýzy pôdorysu vyplýva, že stredný priečny základový pás mal podstatný význam pre konštrukciu a plánovanie celého pôdorysu kostola a že so všetkou pravdepodobnostou plnil funkciu základu predoltárnej priečky. Stredný priečny základový pás preto musel byt’ súčastou primárneho stavebného projektu. Skutočnost', že jeho murivo nie je previazané s obvodovým murivom lode kostola, nie je dôkazom sekundárnosti tejto časti pôdorysu, ale vyplýva zrejme zo skutočnosti, že toto murivo bolo ako základ predoltárnej priečky vytvorené až po vybudovaní základov stavby, hoci jeho poloha musela byt' určená a fixovaná od počiatku stavebných prác, kedže išlo o východiskový prvok pôdorysu. Napokon, základ stavebne samostatnej predoltárnej priečky nemusel byt’ vôbec previazaný s obvodovým murivom. Stredný priečny základový pás preto nie je dokladom novej stavebnej fázy alebo etapy, ${ }^{30}$ ale dokladom postupu pri konštrukcii pôdorysu a hmoty stavby v čase jej vzniku (obr. 7.1).

Dodatočný zásah do základového muriva severnej apsidy sa interpretuje ako statické zabezpečenie základov proti nestabilite klesajúceho svahu v tejto časti pôdorysu (napríklad Vančo 2002, 36; Plachá - Hlavicová 2011,73). Tento výškopisný pokles podložia stavby je faktom. Pri interpretácii doplnenia základov severnej apsidy sa však ignoruje skutočnost', že podobne ako v prípade stredného priečneho základového pásu aj tu ide o architektonickú formu muriva, ktoré so všetkou pravdepodobnostou malo aj nadzákladovú čast. Domurovanie sa nachádza v interiéri i v exteriéri primárneho základu severnej apsidy. Interiérové domurovanie bolo umiestnené len v strede záveru apsidy. Má formu symetrického oblúka (hoci nie presného segmentu kružnice), ktorý zmenšuje hlibku apsidy asi o $60 \mathrm{~cm}$. Exteriérové domurovanie sa nachádza len v severozápadnej časti základov apsidy a v najširšej zachovanej časti je hrubé $60 \mathrm{~cm}$. Má formu oblúka, ktorého priebeh v podstate rešpektuje v určitej vzdialenosti priebeh oblúka interiérového domurovania. Domurovanie v exteriéri je zjavne poškodené, chýba jeho južné pokračovanie, ktoré sa napájalo na severný múr lode, ktorý je v tejto časti rovnako poškodený a znížený až na maltové lôžko. Je zrejmé, že interiérové i exteriérové domurovanie spolu súvisia, tvoria celok, jeden stavebný zásah spočívajúci vo vybudovaní oblúkového muriva hrubého až $140 \mathrm{~cm}$, ktoré z oboch strán čiastočne prekrýva líce muriva severnej apsidy. Tento stavebný zásah treba interpretovat ako prebudovanie muriva severnej apsidy. Pôvodné murivo apsidy nebolo odstránené, ale bolo do tejto premurovky zahrnuté a vo svojej západnej časti sa ocitlo v jadre nového širšieho muriva. Vznikla tak nová apsida vybudovaná s ovela hrubším a stabilnejším murivom. Premurovanie severnej apsidy bolo zrejme naozaj vyvolané statickou poruchou spôsobenou prudko klesajúcim podložím. Tento stavebný zásah možno označit za druhú stavebnú etapu kostola, nie však za druhú stavebnú fázu, kedže sa nemení dispozícia ani štruktúra stavby, ale išlo len o technickú úpravu vyvolanú narušenou statikou (obr. 7.2). K prestavbe severnej apsidy mohlo dôjst' niekol'ko rokov po vzniku stavby, ked' sa statická porucha prejavila do tej miery, že si bud' vyžiadala asanáciu severnej apsidy, alebo došlo dokonca k samovolnej deštrukcii apsidy.

Okolnosti, za ktorých mohol na Vel'kej Morave vzniknút devínsky kostol ako import dalmátskej predrománskej architektúry, možno na základe viacerých indícií týkajúcich sa cirkevných a politických vztahov Vel'kej Moravy, charakteru omietok devínskeho kostola a svedectva písomných prameňov vztahujúcich sa $\mathrm{k}$ Devínu a priestoru Bratislavy datovat’ do 50. - 60. rokov 9. storočia a spojit’ ich s aktivitami kniežat’a Rastislava (Illáš 2011b, 35-36). Kontakty Velkej Moravy s chorvátskou Dalmáciou možno dat' do súvislosti so snahou vel'komoravskej elity nájst’ voči franským a bavorským kňazom alternatívu v iných cirkevných strediskách (Měřínský 2006,

30 Za stavebnú etapu ho považuje T. Rodzińska-Chorąży (2000, 37). 
254-287, 521-523; Illáš 2011b, 34-35). Bez významu však nie sú ani možné osobné či rodinné vztahy Rastislava s Chorvátmi, možno i s trpimírovskými kniežatami (Steinhübel 2012, 161-162). Rastislavov vztah s chorvátskym prostredím môže mat pritom i hlbšie korene: meno Rastislav (zachované vo forme Rastiz, Rastiscolao) ${ }^{31}$ má koreň v slove „rasti“ (Krajčovič 2005, 47). V západoslovanskom - čiže aj velkomoravskom - prostredí však nie je pôvodná forma „rasti“, ale forma „rosti“. Forma „rasti“ je pôvodná v južnoslovanskom prostredí (a v neskoršom vývoji aj v strednej slovenčine, ktorá bola ovplyvnená vo včasnom stredoveku susedstvom s južnoslovanským jazykovým prostredím). ${ }^{32}$ Ak Rastislav dostal meno s týmto južnoslovanským základom, je to zrejme dôsledok toho, že najpravdepodobnejšie jeho matka pochádzala $\mathrm{z}$ južnoslovanského prostredia (otec musel logicky pochádzat' z moravského mojmírovského rodu, ak sa mal Rastislav stat kniežatom; Illáš 2017, 219).

Vznik devínskeho kostola na Vel'kej Morave je teda so všetkou pravdepodobnostou výsledkom aktivít vel'komoravskej elity v oblasti vztahov s cirkvou. Korpus sakrálnej architektúry Velkej Moravy obsahuje i d’alšie stavby, ktoré možno bez väčších pochybností spojit’ s architektúrou v oblasti Jadranu (či už ide o severné Taliansko alebo Dalmáciu). Je to bazilika na Bratislavskom hrade a X. kostol v Mikulčiciach (napríklad Illáš 2011a, 252-270). Možnost takého pôvodu d’alších velkomoravských kostolov (najmä kostolov s polkruhovo ukončenou apsidou), ktoré sa síce často, no nie presvedčivo spájajú s oblastou Jadranu či Balkánu, bude ešte treba podrobne a kriticky preverit.

\section{REFERENCES}

Botek, Andrej. 2014. Vel'komoravské kostoly na Slovensku a odraz ich tradície v neskoršom období. Bratislava.

Cividalské evanjelium. 1999. Cividalské evanjelium. In Marsina, Richard (ed.). Pramene k dejinám Slovenska a Slovákov II - Slovensko očami cudzincov. Budmerice - Bratislava, 169.

Čiháková, Jarmila - Müller, Martin. 2015. Malostranský kostel sv. Václava v geometrickém světě středoevropských rotund. In Staletá Praha, XXXI/1, 2-109.

Dehio, Georg. 1984. Handbuch der Deutschen Kunstdenkmäler. Rheinland-Pfalz und Saarland. Druhé prepracované vydanie. Mníchov.

Fuldské anály. 1966. Annales Fuldenses. In Bartoňková, Dagmar - Havlík, Lubomír - Masařík, Zdeněk - Večerka, Radoslav. (eds.). Magnae Moraviae Fontes Historici I. Praha, 85-129.

Glaser, Franz. 2003. Der frühchristliche Kirchenbau in der nordöstlichen Region (Kärnten/ Osttirol). In Sennhauser, Hans Rudolf (ed.). Frühe Kirchen im östlichen Alpengebiet Von der Spätantike bis in ottonische Zeit. Band 2. Mníchov, 413-437.

Hammer, Ivo. 2008. Restauratorische Befundsicherung an frühmttelalterlichen Wandmalereien des Regnum Maravorum. In Pippal, Martina - Daim, Falko (eds.). Die frühmittelalterlichen Wandmalereien Mährens und der Slowakei. Archäologischer Kontext herstellungstechnische Analyse. Innsbruck, 111-148.

Harmadyová, Katarína. 2012. Devín v 9. a 10. storočí. In Šedivý, Juraj - Štefanovičová, Tatiana (eds.). Dejiny Bratislavy 1. Od počiatkov do prelomu 12. a 13. storočia. Brezalauspurc na križovatke kultúr. Bratislava, 351-359.

${ }_{31}$ Napríklad vo Fuldských análoch „Rastiz“k roku 846 (Annales Fuldenses, anno 864, Fuldské anály 1966, 90) a v margináliách Cividalského evanjeliára „Rastisclao“ (Cividalské evanjelium 1999, 169).

32 K problematike divergencie „rasti“/,rosti“ najmä Krajčovič 1974, 66-67, 113, 118-119, 132-133, mapa č. 15. 
Hecht, Konrad. 1978. Zur Geometrie des St. Galler Klosterplanes. In Abhandlungen der Braunschweigischen Wissenschaftlichen Gesellschaft 29, 57-96.

Chorvátová, Hana. 2017. Niekol'ko poznámok k datovaniu devínskych pohrebísk z 9. storočia v polohe Za kostolom a na hradnom kopci. In Harmadyová, Katarína (ed.). Devín Veroniky Plachej. Zborník k životnému jubileu PhDr. V. Plachej. Bratislava, 115-123.

Illáš, Martin. 2011a. Adriatický pôvod niektorých predrománskych kostolov v strednom Podunajsku. In ARS 44/2, 252-270.

Illáš, Martin. 2011b. Predrománsky kostol na Devíne. In Historický zborník 31/1, 19-39.

Illáš, Martin. 2014. Příspěvek k interpretaci objevu raně středověkého kostela na Vyšehradě. In Pražský sborník historický 42, 159-182.

Illáš, Martin. 2017. Niekol'ko úvah o Pribinovi, Mojmírovcoch a Vel'kej Morave (príspevok k diskusii o včasnostredovekých dejinách Moravy a západného Slovenska). In Moravský historický sborník. Ročenka Moravského národního kongresu 2011 - 2016, 179-247.

Jacobsen, Werner. 1989. Die Abteikirche von Saint-Denis als Kunstgeschichtliches Problem. In Beihefte der Francia 16/2, 151-185.

Jurković, Miljenko. 1988-1989. Problem kontinuiteta između antike i romanike u umjetnosti istočnog Jadrana. In Radovi Institutu za povijest umjetnosti 12-13, 41-48.

Jurković, Miljenko. 2000. Arhitektura karolinškog doba. In Milošević, Ante (ed.). Hrvati i Karolinzi 1. Rasprave i vrela. Split, 164-189.

Krajčovič, Rudolf. 1974. Slovenčina a slovanské jazyky I. Praslovanská genéza slovenčiny. Bratislava. Küntzel, Thomas. 2015. Das Bau-Laboratorium der Bischöfe: Überlegungen zur Kirchenplanung im früh- und hochmittelalterlichen Hildesheim. In Concilium medii aevi 18, 1-60.

Lurker, Manfred. 2005. Slovník symbolů. Praha.

Marasović, Tomislav. 2008. Dalmatia Praeromanica. Ranosrednjovjekovno graditeljstvo u Dalmaciji 1. Rasprava. Split - Záhreb.

Marasović, Tomislav. 2009. Dalmatia Praeromanica. Ranosrednjovjekovno graditeljstvo u Dalmaciji 2. Korpus arhitekture. Kvarner i Sjeverna Dalmacija. Split - Záhreb.

Marasović, Tomislav. 2011. Dalmatia Praeromanica. Ranosrednjovjekovno graditeljstvo u Dalmaciji 3. Korpus arhitekture. Srednja Dalmacija. Split - Záhreb.

Měřinský, Zdeněk. 2006. České země od příchodu Slovanů po Velkou Moravu II. Praha.

Pejaković, Mladen. 2000. Zlatni rez. Zagreb.

Plachá, Veronika - Hlavicová, Jana. 1981. Výsledky archeologického výskumu na hrade Devín v roku 1980. In AVANS 1, 234-235, 435-436.

Plachá, Veronika - Hlavicová, Jana. 2011. Ranostredoveký Devín. Bratislava.

Plachá, Veronika - Hlavicová, Jana - Keller, Igor. 1990. Slovanský Devín. Bratislava.

Poláček, Lumír. 2008. Altmährische Kirchen als archäologische Quelle. In Pippal, Martina Daim, Falko. (eds.) Die frühmittelalterlichen Wandmalereien Mährens und der Slowakei. Archäologischer Kontext herstellungstechnische Analyse. Innsbruck, 11-30.

Pošmourný, Josef. 1964. Církevní architektura Velkomoravské říše. In Umění 2, 187-202.

Rodzińska-Chorąży, Teresa. 2000. Vel'komoravská trikoncha na Devíne: medzi antikou a stredovekom. In Bořutová, Dana - Oriško, Štefan. (eds.). Pocta Václavovi Menclovi. Zborník štúdií k otázkam interpretácie stredoeurópskeho umenia. Bratislava, 33-58.

Ruttkay, Alexander T. 2012. Najstaršie sakrálne stavby na Slovensku ako odraz christianizácie a budovania krestanských inštitúcií v 9. - 11. storočí. In Panis, Branislav - Ruttkay, Matej Turčan, Vladimír. (eds.). Bratia, ktorí menili svet - Konštantín a Metod. Príspevky z konferencie (Bratislava 21. februára 2013). Bratislava, 79-98. 
Samuel, Marián - Pomfyová, Bibiana. 2015. Bratislava, čast’ Devín, hrad. Zaniknuté ranostredoveké sakrálne stavby. In Pomfyová, Bibiana (ed.). Stredoveký kostol. Historické a funkčné premeny architektúry. Bratislava, 97-100.

Sennhauser, Hans Rudolf. 2003. Katalog der frühchristlichen und frühmittelalterlichen kirchlichen Bauten in der Diözese Chur und in den nördlich und südlich angrenzenden Landschaften (A1-A125). In Sennhauser, Hans Rudolf. (ed.) Frühe Kirchen im östlichen Alpengebiet Von der Spätantike bis in ottonische Zeit. Band 1. Mníchov, 43-222.

Steinhübel, Ján. 2012. Moravania, Chorváti a Bulhari v plánoch pápežskej kúrie (860-880). In Panis, Branislav - Ruttkay, Matej - Turčan, Vladimír. (eds.). Bratia, ktorí menili svet - Konštantín a Metod. Príspevky z konferencie (Bratislava 21. februára 2013). Bratislava, 157-174.

Struhár, Alojz. 1977. Geometrická harmónia historickej architektúry na Slovensku. Bratislava. Štefanovičová, Tatiana. 1989. Osudy starých Slovanov. Martin.

Štefanovičová, Tatiana et al. 1993. Najstaršie dejiny Bratislavy. Bratislava.

Vančo, Martin. 1998. Kaplnka sv. Margity Antiochijskej pri Kopčanoch. In Slovácko 40, 123-134.

Vančo, Martin. 2000. Stredoveké rotundy na Slovensku (9. - 13. storočie). Bratislava.

Vančo, Martin. 2002. Počiatky krestanskej architektúry - Vel'komoravská sakrálna architektúra na Slovensku. In Bakoš, Ján et al. (eds.). Problémy dejín výtvarného umenia Slovenska. Bratislava, 19-53.

Vančo, Martin. 2011. K metodologii výzkumu velkomoravské architektury. In Acta historica Neosoliensia 14/1-2, 128-164.

Vežić, Pavuša. 2011. Dalmatinski trikonhosi. In Ars adriatica 1, 27-66.

Vitruvius 1979. Vitruvius, Deset knih o architektuře. Preklad Alois Otoupalík. (= Antická knihovna, sv. 42). Praha.

\section{SUMMARY: RELATION OF THE PRE-ROMANESQUE CHURCH AT DEVÍN} TO DALMATIAN ARCHITECTURE. The subject of this study is the structural and iconographic-iconological analysis of the ground-plan of the early-medieval church in Devín Castle. The study also attempts to define the construction phases or building stages that can be identified in the building development of the ground-plan.

The foundations of the building were archaeologically researched in 1921-22, 1935 and 1980 when its complete ground-plan was uncovered and the building was interpreted as a church and dated back to the 2 nd half of the 9 th century.

The early-medieval church at the Devín Castle is exceptional among the examples of the sacred architecture of the Central Europe in the 9th century. It is a triconch with three identical juxtaposed apses placed on a U-plan. The longitudinal nave is divided by three transverse foundation stripes of which the middle one is not bound with the foundation of the perimeter walls. The foundation of the northern apse was later supplemented in interior and exterior by a mantle.

Spatial and functional layout of the church is the subject of diametrically different interpretations. Some of them can be ruled out as unlikely or unrealistic, especially the interpretation of a palace with the palace chapel, which should be the oldest example of the connection of a profane and sacral structure in the Central European environment and whose younger examples are known from several Polish sites from the 2nd half of the 10th and the 11th century. Similarly, the identification of the provenance of this building is the subject of various interpretations, from Longobard and Roman court representational architecture through Dalmatian or Balkan architecture to Byzantine architecture.

After a critical analysis, the building is most likely to be interpreted as a church with one undivided longitudinal nave. This view is supported by the formal analysis of the layout of this building and its comparison with analogically arranged churches from the 5th 
to the 6th century in Dalmatia and Noricum (St. John the Baptist Church in Sutivan, St. Martin Church in Pridraga, church with unknown dedication in Bilice and St. Peter Church in Lendorf-Holz). Three of them served as churches still in the early-Middle Ages. In the St. John the Baptist Church in Sutivan, there is a foundation stripe carrying only a pair of the interior lisenas, not a wall. Therefore the transverse foundation stripes in the Devín church may also be interpreted as the foundations for the interior lisenas.

The Devín church apparently presents an early-medieval adaptation of a defined model of the Dalmatian late-antique church through Dalmatian pre-Romanesque architecture.

For the complete comparison of the Devín church with its Dalmatian late-antique analogies, it is necessary to perform the structural and iconographic-iconological analyzes of their ground-plans.

From the analysis of 52 parameters of the ground-plan of the Devín church, 31 can be figured in Roman feet $(30 \mathrm{~cm})$ and 27 in Carolingian feet $(33.3 \mathrm{~cm})$.

On the ground-plan of the Devín church, several construction plans based on different planimetric methods of construction can be applied: dynamic squares, quadratures, $\mathrm{X}$-figures and circles. The basis of each of the applied design plans is one basic source dimension, i. e. module.

All applied construction plans are directly or indirectly derived from the central transverse foundation stripe. The middle transverse foundation stripe therefore had to be of fundamental importance for the spatial and functional layout of the church. It seems most likely it served as a septum, i. e. a chancel screen.

Two of the construction plans define four areas, which can be interpreted as a reduced narthex or pronaos, a nave and a presbytery consisting of an altar space and a sanctuary. The location of the altar can be assumed on the eastern transverse foundation stripe.

The identification of the construction plans and their modules allows to define four ground-plan parameters representing the modules. It is the exterior nave width $(680 \mathrm{~cm})$, the total interior width of the presbytery $(1145 \mathrm{~cm})$, the interior width of the nave $(540 \mathrm{~cm})$ and the interior diameter of the apse $(340 \mathrm{~cm})$. All four modules can be figured in Carolingian feet while in Roman feet can be figured only two of them. It is therefore likely that the groundplan of the Devín church was constructed using a Carolingian foot.

In the plan of the three Dalmatian triconchs, it is possible to identify the construction plans analogous to one of the construction plans applied in the ground-plan of the Devín church. These construction plans defined functionally determined areas: an entrance travé, a nave (quadratum populi) and a triconch presbytery (including diakonikon, prothesis, subsellia).

The Devín church therefore corresponds with the three Dalmatian triconchs not only with the formal features of the plan layout, but also with some dimensions as well as the construction plan.

The ground-plan of the Devín church was in principle a result of one building project, not more of them. Two ground-plan elements are obviously the separate building interventions. The first one is the middle transverse foundation stripe which has not been bound with the perimeter foundation, the second one is the additional reinforcement of the wall of the northern apse. The middle transverse foundation stripe served most likely as the base of the chancel screen. The additional intervention in the masonry of the northern apse is usually interpreted as static securing of the foundations. This additional foundation has a form of a symmetrical arc. It can be interpreted as a rebuilding of the northern apse. The rebuilding of the northern apse was apparently caused by a static disorder caused by rapidly descending subsoil, when it was either broken down or it collapsed itself.

The circumstances of the origin of the Devín church were probably related to the activities of prince Rastislav in the 50s and 60s of the 9th century aimed to find an alternative to the Frankish and Bavarian priests in other church centres, especially in southern Europe. Also the personal or family relations between Rastislav and the Croatian princes are not excluded. 
MARTIN ILLÁš

Mgr. Martin Illáš

Ministry of Agriculture and Rural Development of the Slovak Republic

Dobrovičova 12

81109 Bratislava

Slovakia

martin.illas2@gmail.com 


\section{Prílohy / Appendix}

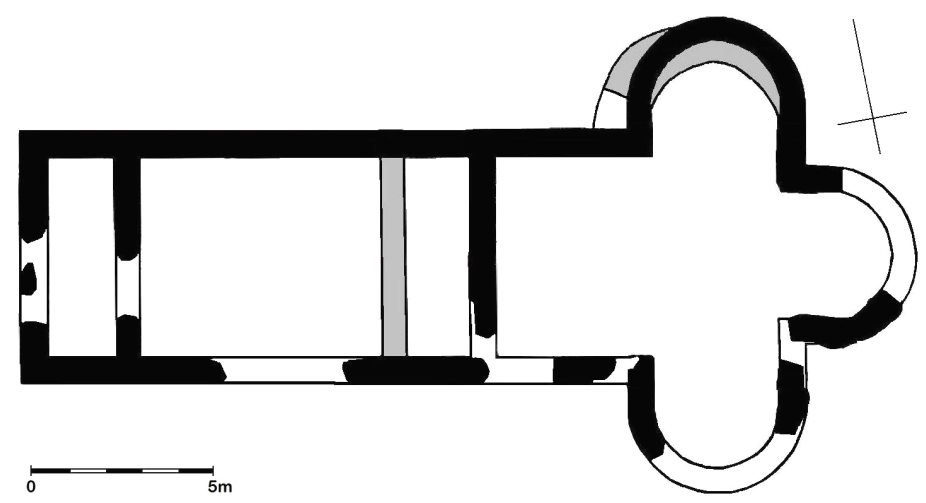

Obr. 1. Pôdorys kostola na Devíne. Repro: Upravené a doplnené podla Plachá - Hlavicová - Keller 1990, s. 90 .

Fig. 1. The ground-plan of the Devín church. Repro: Adapted and completed by Plachá - Hlavicová - Keller $1990,90$.
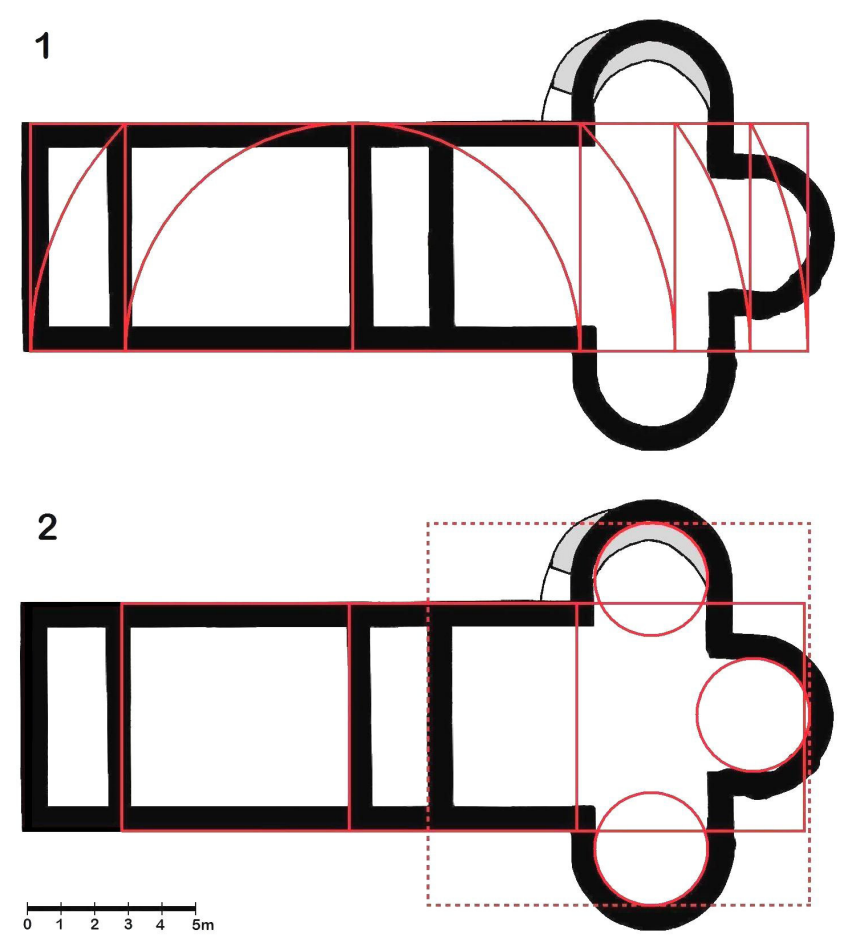

Obr. 2. Konštrukčné plány pôdorysu kostola na Devíne: 2.1. Konštrukčný plán založený na dynamických štvoruholníkoch; 2.2. Prvý a druhý konštrukčný plán založený na kvadratúrach a konštrukčný plán kružníc. Kresba: M. Illáš.

Fig. 2. The construction plans of the ground-plan of the Devín church: 2.1. Construction plan based on dynamic squares; 2.2. The first and second construction plan based on the quadratures and construction plan of the circles. Drawing: M. Illáš. 


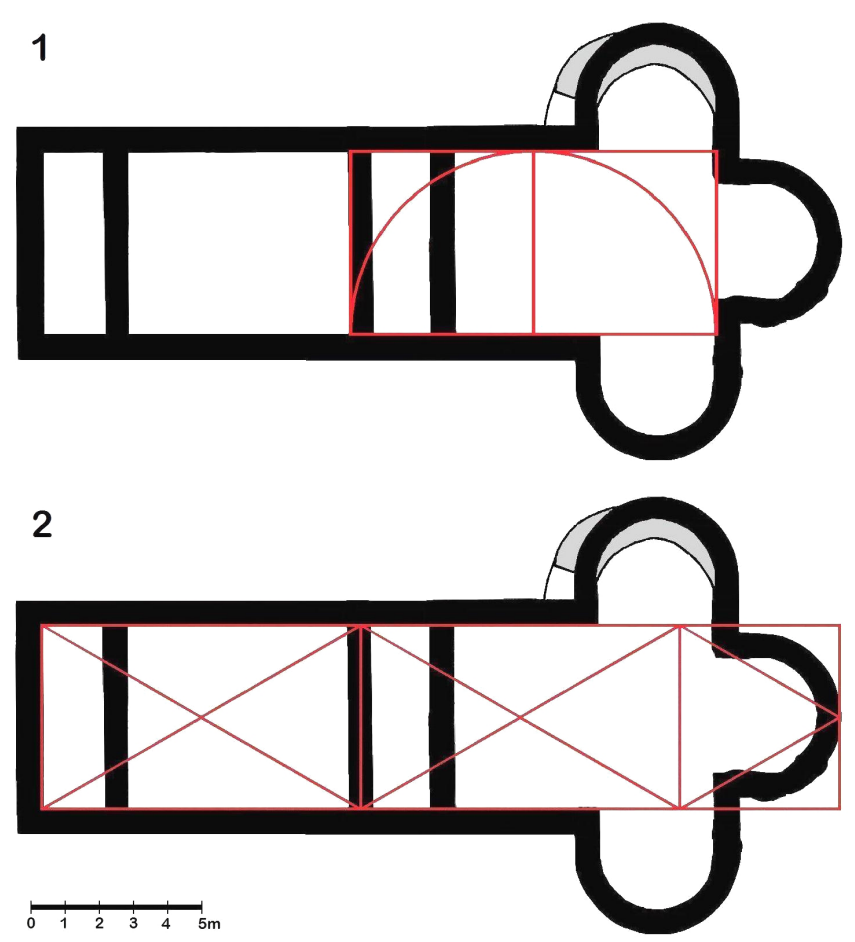

Obr. 3. Konštrukčné plány pôdorysu kostola na Devíne: 3.1. Tretí konštrukčný plán založený na kvadratúrach; 3.2. Konštrukčný plán založený na X-figúrach. Kresba: M. Illáš.

Fig. 3. The construction plans of the Devín church: 3.1. The third construction pla based on the quadratures; 3.2. Construction plan based on the X-figures. Drawing: M. Illáš.

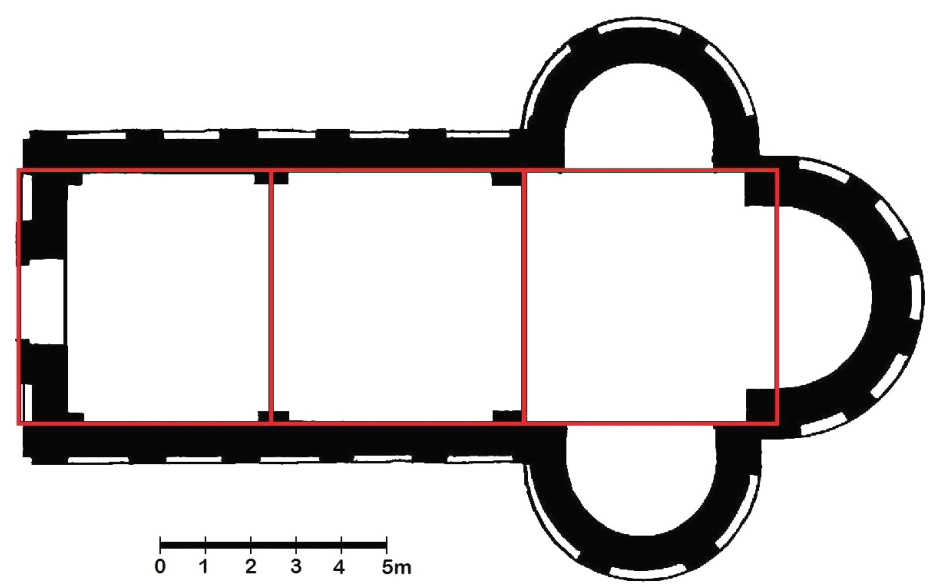

Obr. 4. Konštrukčný plán pôdorysu kostola v Biliciach založený na kvadratúrach. Repro: Upravené a doplnené podla Vežić 2011, 37, 42.

Fig. 4. The construction plan of the ground-plan of the Bilice church based on the quadratures. Repro: Adapted and completed by Vežić 2011, 37, 42. 


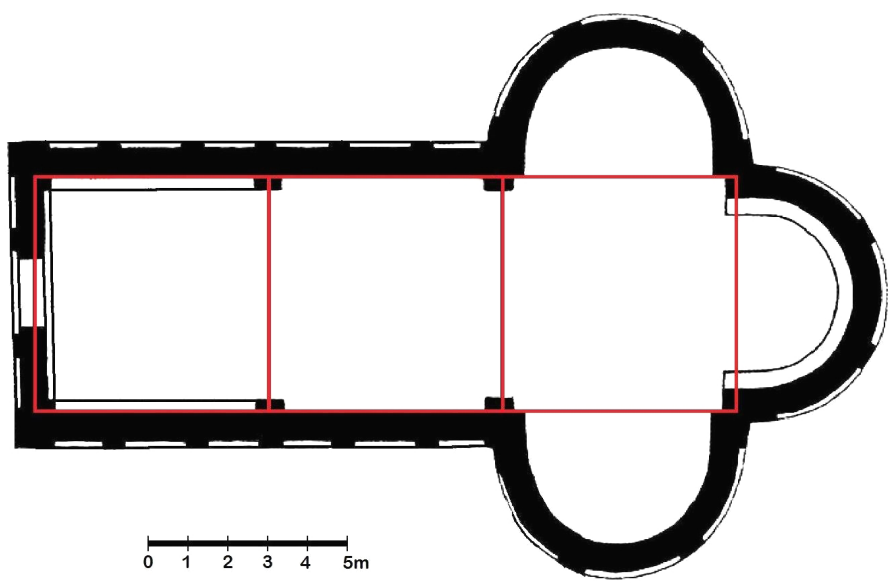

Obr. 5. Konštrukčný plán pôdorysu kostola sv. Martina v Pridrage založený na kvadratúrach. Repro: Upravené a doplnené podla Vežić 2011, 34, 40.

Fig. 5. The construction plan of the ground-plan of the St. Martin church in Pridraga based on the quadratures. Repro: Adapted and completed by Vežić 2011, 34, 40.

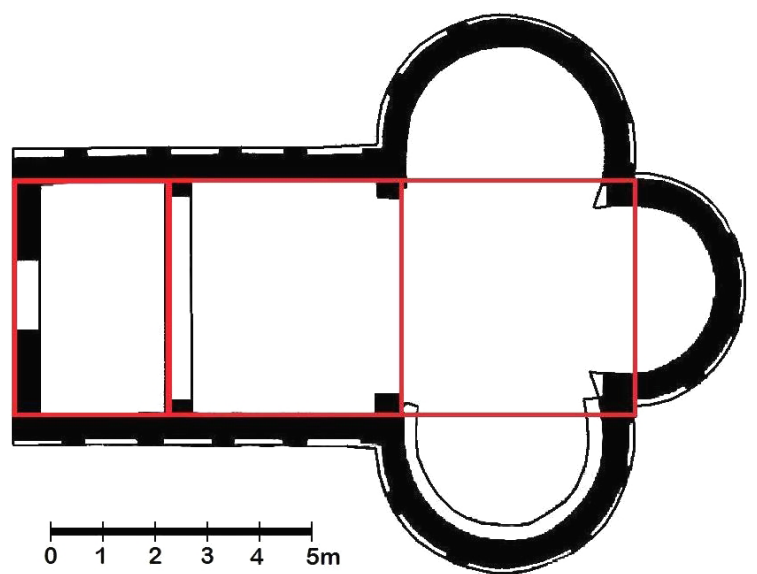

Obr. 6. Konštrukčný plán pôdorysu kostola sv. Jána Krstitela v Sutivane založený na kvadratúrach. Repro: Upravené a doplnené podla Vežić 2011, 38, 43.

Fig. 6. The construction plan of the ground-plan of the St. John the Baptist church in Sutivan based on the quadratures. Repro: Adapted and completed by Vežić 2011, 38, 43. 


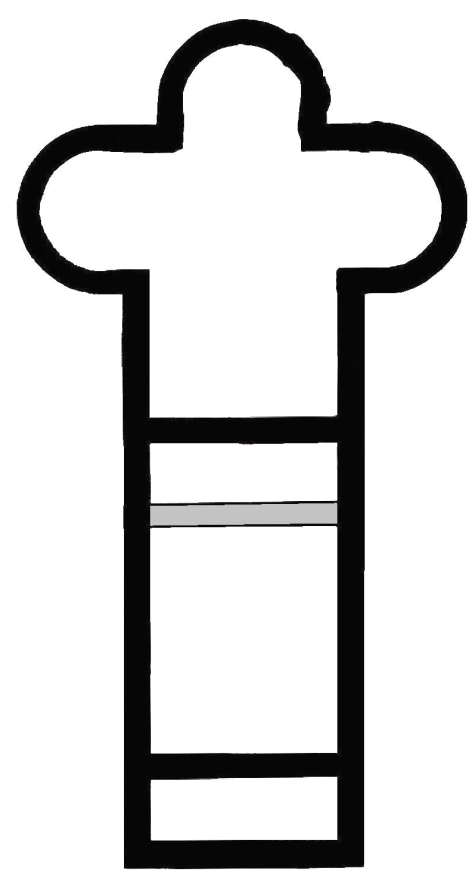

1

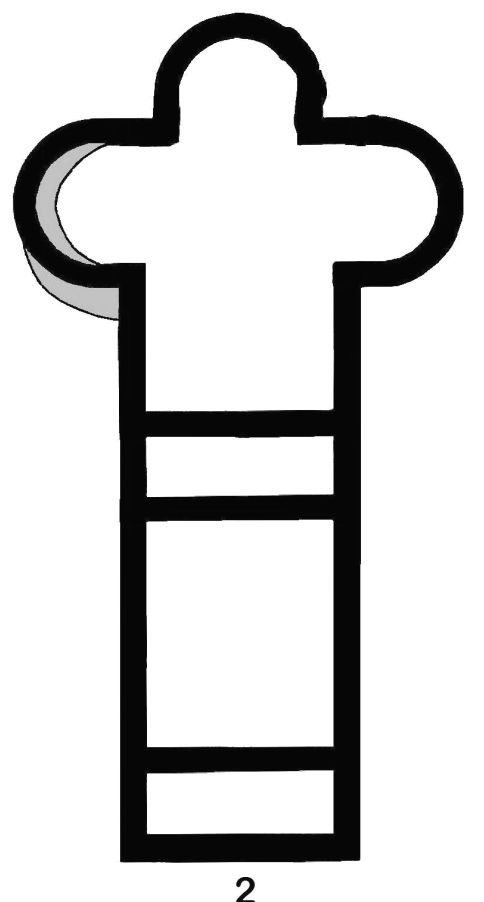

2

Obr. 7. Etapy stavebného vývoja pôdorysu kostola na Devíne: 7.1. Prvá etapa s konštrukčne samostatným stredným priečnym základovým pásom. 7.2. Druhá etapa s prestavbou severnej apsidy. Repro: Upravené a doplnené podla Plachá - Hlavicová - Keller 1990, 90.

Fig. 7. The building development stages of the ground-plan of the Devín church: 7.1. The first stage with the structural independent middle transverse foundation stripe. 7.2. The second stage with rebuilding of the northern apse. Repro: Adapted and completed by Plachá - Hlavicová - Keller 1990, 90. 